\title{
INTERVENSI PEMERINTAH TERHADAP PENDIDIKAN MASYARAKAT PUTUS SEKOLAH KECAMATAN TANETE RIAJA KABUPATEN BARRU
}

\author{
Roy Hartono ${ }^{1}$, Kaharuddin ${ }^{2}$, Sudarsono ${ }^{3}$ \\ ${ }^{1}$ Pendidikan Sosiologi, Universitas Muhammadiyah Makassar \\ Email: royhartono191@gmail.com \\ ${ }^{2}$ Pendidikan Sosiologi, Universitas Muhammadiyah Makassar \\ Email: kaharuddin@unismuh.ac.id \\ ${ }^{3}$ Pendidikan Sosiologi, Universitas Muhammadiyah Makassar \\ Email: sudarsono@unismuh.ac.id
}

\begin{abstract}
Abstrack. The objective of this research were to find out how the form of social change in the Tanete Riaja community Barru Regency interaction occurs the Government and the Community to find out what factors are affecting so that there are children who are unable to go to school.

This research used qualitative method and the location of the study is in Tanete Riaja District, Barru Regency. Sampling technique is by determining its own characteristics (purposive sampling) and data collection techniques are carried out using primary data and secondary data through observation, interviews and documentation.

The findings of this research that are a form of social change in the Tanete Riaja Subdistrict are changes that slowly bring direct influence means that the people in the Tanete Riaja Subdistrict can be said to have entered a progressive level of education because of government assistance both through informally and informally As for Government assistance, such as scholarship assistance for those who are less fortunate and scholarships for those who excel and other assistance such as books.
\end{abstract}

Keywords: Intervention, Government and Education

Abstrak. Penelitian ini bertujuan untuk mengetahui bagaimana bentuk perubahan sosial pada masyarakat Tanete Riaja Kabupaten Barru interaksi yang terjadi Pemerintah dan Masyarakat untuk mengetahui faktorfaktor apa saja yang mempengaruhi sehingga adanya anak yang tak mampu sekolah.

Penelitian ini menggunakan metode kualitatif dan adapun lokasi penelitian yaitu di Kecamatan Tanete Riaja Kabupaten Barru. Teknik pengambilan sampling yaitu dengan cara menentukan karakteristik sendiri (purposive sampling) dan teknik pengumpulan data yang dilakukan dengan menggunakan data primer dan data sekunder melalui observasi, wawancara dan dokumentasi.

Hasil penelitian ini yaitu yang menjadi bentuk perubahan sosial di Kecamatan Tanete Riaja adalah Perubahan secara perlahan yang membawa pengaruh secara langsung berarti masyarakat di Kecamatan Tanete Riaja ini bisa dikatakan sudah memasuki tingkat pendidikan yang berkemajuan karena berkat adanya bantuan pemerintah baik melalui secara informal maupun secara non formal adapun bantuan Pemerintah yaitu seperti bantuan beasiswa bagi mereka yang kurang mampu dan beasiswa bagi yang berprestasi dan bantuan lainnya seperti buku.

Kata Kunci : Intervensi, Pemerintah dan Pendidikan. 


\section{PENDAHULUAN}

Majunya suatu negara dipengaruhi oleh banyak faktor, salah satu faktor yang sangat penting mendorong majunya suatu negara adalah pendidikan. Tanpa pendidikan tidak mungkin suatu negara dapat maju. Karena dari pendidikanlah seseorang dapat belajar, dari yang tidak tahu menjadi tahu dan dari yang tidak bisa menjadi bisa. Menurut Undang- Undang Republik Indonesia Nomor 20 tahun 2003 tentang Sistem Pendidikan Nasional, pendidikan adalah usaha sadar dan terencana untuk mewujudkan suasana belajar dan proses pembelajaran agar peserta didik secara aktif mengembangkan potensi dirinya untuk memiliki kekuatan spiritual keagamaan, pengendalian diri, kepribadian, kecerdasan, akhlak mulia, serta keterampilan yang diperlukan dirinya, masyarakat, bangsa dan negara.

Berawal dari pendidikan seseorang dapat mengembangkan potensi yang ada di dalam dirinya. Setiap manusia memiliki potensinya masing masing, hanya saja bagaimana caranya seseorang itu menggali dan mengembangkan potensi yang dimilikinya. Melalui pendidikan manusia bisa melakukan hal itu. Bukan hanya mengembangkan potensi diri, manusia dapat memiliki kekuatan spiritual keagamaan. Di dalam pendidikan di Indonesia, sedari kecil ditanamkan nilai-nilai religiusitas yang taat kepada Tuhan. Dengan begitu manusia dapat hidup terat.

Banyak faktor yang melandasi tingginya tingkat putus sekolah. salah satunya adalah faktor ekonomi, kurangnya lapangan pekerjaan, kurangnya dorongan dari orang tua dan lain sebagainya. Perlunya kesadaran bagi anak dan orang tua akan pentingnya pendidikan. Fasilitas yang disediakan oleh pihak sekolah juga merupakan faktor pendorong tingginya tingkat putus sekolah. Pengajar yang monoton menjadikan anak-anak bosan untuk belajar, terlebih pada tingkat Sekolah TK, SD, SMP, SMA dan sebagainya.

Upaya yang telah dilakukan oleh pemerintah melalui berbagai paket program pendidikan sebagai impelementasi penggunaan anggaran pendidikan $20 \%$ dari APBN, utamanya di daerahdaerah tertinggal masih sangat minim dibandingkan dengan kebutuhan masyarakat. Programprogram yang dibuat oleh pemerintah seringkali hanya program tambal sulam (incremental) dan tidak berkelanjutan (sustainable). Banyaknya sekolah, utamanya sekolah dasar yang dalam kondisi rusak berat dan hanya direhabilitasi melalui Biaya Orientasi Sekolah (BOS) dan berbagai paket program sejenis lainnya, tidaklah menjadikan sarana dan prasarana pendidikan tersebut menjadi lebih baik. Banyaknya sekolah dasar yang rusak tersebut menyebabkan anak-anak usia pendidikan dasar tidak merasa nyaman dalam proses pembelajaran.

Diperlukannya kesadaran masyarakat untuk mendukung pendidikan dan memotivasi anak semangat dalam belajar. Dibutuhkan juga peran dari masyarakat luar yang sudah mengerti betapa pentingnya pendidikan untuk datang mendukung dan memotivasi anak-anak untuk sekolah. Melihat fenomena-fenomena seperti itu yang masih banyak terdapat di Indonesia, khususnya di masyarakat Kecamatan Tanete Riaja Kabupaten Barru. Munculah berbagai gerakan yang berfokus di bidang pendidikan. Mulai dari ruang lingkup nasional hingga lingkungan masyarakat pedesaan, pemerintah tetapi tugas semua bangsa Indonesia. Pemerintah tidak akan dapat mewujudkan janji kemerdekaan tanpa bantuan bangsa Indonesia.

\section{KAJIAN PUSTAKA}

Lahirnya Teori Fungsionalisme Strutural didorong oleh karya-karya klasik dari Tallcot Parson, sosiolog Prancis." Menurut Tallcot Parson, masyarakat merupakan keseluruhan organis yang memiliki realita tersendiri. Keseluruhan tersebut memiliki seperangkat kebutuhan atau fungsi-fungsi tertentu yang harus dipenuhi oleh bagian-bagian yang menjadi anggotanya, agar dalam keadaan normal, tetap langgeng. Dalam teori fungsional dikatakan bahwa sistem pendidikan moderen berasal dari dan meluas sebagai akibat berubahnya kebutuhan fungsional. Pendidikan harus diperluas agar memberi kepada orang-orang latihan yang mereka perlukan untuk berfungsi secara efektif dalam dunia pekerjaan. Dengan demikian, pendidikan diharuskan untuk selalu mengikuti perkembangan yang terjadi, baik dalam pembelajaran, kurikulum, alat serta dukungan publik, termasuk para 
pemangku kepentingan. Jika tidak demikian, pendidikan akan berjalan lamban, sementara perubahan terjadi sangat cepat, sehingga pendidikan selalu ketinggalan dan tidak bisa menyesuaikan diri dengan perubahan yang terjadi di masyarakat.

Sistem pendidikan juga dilihat sebagai suatu struktur yang mengisi persyaratan fungsional. Sistem okupasional (penempatan jabatan) memerlukan sejumlah tenaga yang memiliki keterampilan yang sesuai, pengetahuan dan komitmen motivasional dasar pada pola prestasi universalistik. Pendidikan memberikan keterampilan dasar yang dibutuhkan untuk mengambil bagian secara berarti dalam kehidupan masyarakat dengan suatu dasar yang lebih sistimatis.

Untuk mengantisipasi kemajuan yang ada dalam masyarakat, termasuk dunia pendidikan, teori fungsional mengemukakan seperangkan empat persyaraan fungsional yang harus dipenuhi oleh sistim sosial. Keempat persyatan itu dalam teori fungsional dikenal dengan bagan A-G-I-L yang merupakan singkatan dari Adaptation, Goal Attainment, Integration, dan Laten Pattern Maintenance.

Adaptation, menunjuk pada keharusan sistem-sistem soial untuk menghadapi lingkungannya, dengan harus mengadakan penyesuaian diri terhadap tuntutan kenyataan yang keras dan tidak dapat diubah (inflexible) yang datang dari lingkungan.

Goal Attainment, yakni bahwa setiap tindakan itu diarahkan pada tujuan bersama para anggota dalam sistem sosial, hukan tujuan yang bersifat pribadi. Untuk mencapai tujuan itu diharuskan adanya npengmbilan keputusan yang berhubungan dengan prioritas dari sekian banyak tujuan. Integration, merupakan persyaratan yang berhubungan dengan interalasi antara anggota dalam sistem sosial. Supaya sistem sosial berfungsi secara efektif sebagai suatu kesatuan harus ada solidaritas antara orang-orang yang ada di dalamnya. Laten Pattern Maintenence (Pemeliharaan Pola) Pendidikan harus menyesuaikan tujuan dengan kemajuan teknologi dalam masyarakat. Di dalam pendidikan harus dirumuskan tujuan yang jelas, yang menjadi tujuan bersama, sehingga membutuhkan hubungan yang kuat antara komponen dalam sistem pendidikan. Hal ini penting untuk mempertahankan nilai-nilai yang dianut bersama. Jika tidak ada keinginan untuk mempertahankan nilai-nilai itu, maka pendidikan dihadapkan pada situasi yang tidak menentu, akan terjadi kekacauan dalam pelaksanaan pendidikan.

Untuk mempertahankan hal itu, dibutuhkan upaya untuk menjaga dan melaksanakan pendidikan dalam bentuk peraturan perundang-undangan yang berhubungan dengan pendidikan, termasuk kegiatan pembelajaran. Demikian pula halnya dengan teori fungsional dengan empat langkah yang menjadi ciri teori fungsional, maka lembaga persekolahan saat ini menghadapi kenyataan yang tidak dapat diubah atau dikendalikan sesuai keinginan, yakni kemajuan ilmu pengetahuan dan teknologi yang amat pesat. Lembaga persekolahan sebagai sistem sosial mau atau tidak mau, jika ingin bertahan, harus menyesuaikan diri dengan kemajuan dan perkembangan ilmu pengetahuan dan teknologi. Salah satu komponen yang bertanggung jawab dalam sistem pendidikan, adalah guru.

\section{METODE PENELITIAN}

Jenis penelitian yang digunakan dalam penelitian ini berupa penelitian deskriptif kualitatif. Alasan memilih jenis penelitian tersebut yaitu untuk menggambarkan dan mendeskriftifkan secara mendalam terkait dengan "Intervensi Pemerintah Terhadap Kemajuan Pendidikan Masyarakat Tanete Riaja Kabupaten Barru".

Pendekatan yang digunakan yaitu kualitatif Alasan peneliti karena dalam penelitian ini kita dituntut untuk memperdalam data (indep interview), karena metode kualitatif adalah suatu prosedur penelitian yang menghasilkan data deskriptif ucapan atau tulisan dan perilaku yang dapat diamati dan orang-orang (subjek) itu sendin Penelitian dengan mengacu pada gambar deskriptif data, diperoleh dan informasi sebagai subjek penelitian dengan demikian peneliti dapat mengetahui sebab maupun akibat dan permasalahan yang ada dalam penelitian deskriptif. Ucapan atau tulisan dan perilaku yang dapat diamati dari (subjek) itu sendiri. 
Hal-hal yang menjadi sasaran penelitian dalam peneliatn ini adakah Intervensi Pemerintah Terhadap Kemajuan Pendidikan Masyarakat Tanete Riaja Kabupaten Barru. Dalam penelitian Teknik pengambilan informan yang di gunakan penelitian adalah purposive sampling yaitu teknik pengambilan sampel sumber data, yang pada awalnya jumlahnya sedikit, lama-lama menjadi besar. Hal ini dilakukan karena dari jumlah sumber data yang sedikit tersebut, belum mampu memberikan data yang lengkap, peneliti mencari orang lain lagi yang dapat digunakan sebagai sumber data.

Jenis data dalam penelitian ini yakni Jenis Data (diperoleh melalui media) Sumber Data (langsung dari objek). Adapun Teknik pengumpulan data yang dilakukan dalam penelitian ini adalah: observasi, dokumentasi dan wawancara. Untuk memperoleh hasil penelitian yang lengkap, tepat dan benar, maka diperlukan metode yang valid dalam menganalisa data.

\section{HASIL PENELITIAN DAN PEMBAHASAN}

1. Hasil Penelitian

a. Bagaimana Interaksi dan Intervensi Pemerintah Terhadap Kemajuan Pendidikan di Kecamatan Tanete Riaja Kabupaten Barru.

Interaksi Pemerintah merupakan salah satu bentuk sosialisasi antara Pemerintah dan Masyarakat khususnya Anak yang tidak mampu menempuh jenjang pendidikan yang ada di daerah kecamatan Tanete Riaja Kabupaten barru yang memberikan pengaruh yang besar. Pada hakikatnya, faktor lingkungan sangat berperan dalam mendukung pembetukan akhlak Anak, yang akan Nampak setelah anak meningkat umur ke jenjang kedewasaan interaksi social yang wajar antara anak dengan anggota-anggota masyarakat nilai-nilai perilaku, norma-norma agama dan sosial merupakan peraturan yang harus di patuhi oleh setiap induvidu yang ada dalam kelompok. Perkembangan sosial merupakan pencapaian kematangan dalam hubungan sosial. Dapat juga di katakan sebagai proses belajar untuk menyusuaikan diri terhadap norma-norma kelompok, Moral dan tradisi, dalam dunia pendidikan, pembinaan akhlak dititik beratkan pada pembentukan perilaku agar anak tidak mengalami penyimpangan.

Dengan demikian, anak tidak mengalami "Juvenile Deliquency" (kenakalan remaja) yang berarti kenakalan anak. Sebab dalam pembinaan perilaku di tekankan bahwa anak di tuntut untuk belajar memiliki rasa tanggung jawab. bukan saja menjadi tanggung jawab pemerintah, melainkan tanggung jawab seluruh rakyat Indonesia. Hal ini berarti bahwa pembangunan pendidikan nasional tidak hanya mengejar kemapuan lahirlah semata-mata tetapi butuh kesalarasan dan keseimbangan. Dengan demikian undang-undang ini jelas bahwa pemerintah pusat mengingatkan segala bentuk program nasional bisa di berdasarkan oleh setiap masyarakat di daerah-daerah. kesimpulan bahwa ada banyak bantuan pemerintah yang mefasilitasi pendidikan yang ada khususnya di kecamatan tanete riaja dan betapa pendidikan yang harus di tempuh agar tidak tertinggal jauh dan petingnya juga alat teknologi seiring berjalannya zaman.

\section{b. Apa Implikasi Pendidikan di Kecamatan Tanete Riaja Terhadap Masyarakat Kabupaten Barru}

Pentingnya pendidikan merupakan sebagai pilar utama peningkatan kualitas sumber daya manusia dan mengembangkan kemampuan dan membentuk watak serta peradaban bangsa yang bermartabat dalam rangka mencerdaskan kehidupan bangsa, bertujuan untuk berkembangnya potensi peserta didik agar menjadi manusia yang beriman dan bertakwa kepada Allah swt, berakhlak mulia, sehat, berilmu, kreatif, mandiri dan menjadi warga negara yang demokratis serta bertanggung jawab.

Partisipasi Pemerintah terhadap masyarakat sering dianggap sebagai bagian yang tidak terlepas dalam upaya sosialisasi dengan anak yang tertinggal oleh pendidkan dan tidak dapat terlepas dari peran serta masyarakat kususnya orang tua. Orang tua perlu aktif berpartisipasi dan memberikan dorongan agar mau menempuh pendidikan, sehingga mampu mengembangkan dayanya secara kreatif serta memiliki kesadaran kritis. pentinya pendidikan itu pada anak yang tak mampu sekolah karena Pendidikan dapat mengembangkan kemampuan dan membentuk watak serta peradaban 
bangsa yang bermartabat dalam rangka mencerdaskan kehidupan bangsa, bertujuan untuk berkembangnya potensi peserta didik agar menjadi manusia yang beriman dan bertakwa kepada Allah SWT, berakhlak mulia, sehat, berilmu, kreatif, mandiri dan menjadi warga negara yang demokratis serta bertanggung jawab.

\section{PEMBAHASAN}

\section{a. Bagaimana Interaksi dan Intervensi Pemerintah Terhadap Kemajuan Pendidikan di Kecamatan Tanete Riaja Kabupaten Barru.}

Saat ini, perkembangan pendidikan di masyarakat Tanete Riaja sudah berkemajuan yang saling berhubungan timbal balik. Berkat adanya interaksi interaksi dan perhatian pemerintah dimana masyarakat atau orang tua mampu memberikan motivasi kepada anak yang tidak mampu sekolah mengenai pendidikan bahwa pendidikan Pada hakikatnya, faktor lingkungan sangat berperan dalam mendukung pembetukan akhlak Anak, yang akan Nampak setelah anak meningkat umur ke jenjang kedewasaan interaksi social yang wajar antara anak dengan orang tua masyarakat nilai-nilai perilaku, norma-norma agama dan sosial merupakan peraturan yang harus di patuhi oleh setiap induvidu yang ada dalam kelompok. Perkembangan sosial merupakan pencapaian kematangan dalam hubungan sosial.

Dapat juga di katakan sebagai proses belajar untuk menyusaikan diri terhadap norma-norma kelompok, Moral dan tradisi, dalam dunia pendidikan, pembinaan akhlak dititikberatkan pada pembentukan perilaku agar anak tidak mengalami penyimpangan. Dengan demikian, anak tidak mengalami" Juvenile Deliquency" (kenakalan remaja) yang berarti kenakalan anak. Sebab dalam pembinaan perilaku di tekankan bahwa anak di tuntut untuk belajar memiliki rasa tanggung jawab. bukan saja menjadi tanggung jawab pemerintah, melainkan tanggung jawab seluruh rakyat Indonesia. Interaksi arti dari Hubungan timbal balik antara individu dengan individu, individu dengan kelompok, maupun kelompok satu dengan lainnya. Faktor-faktor yang mendorong terjadinya interaksi pemerintah dan masyarakat.

Proses interaksi sosial biasanya didasari oleh beberapa faktor, seperti sugesti, imitasi, identifikasi, simpati, motivasi, dan empati. Teori interaksi simbolik yang digagas oleh George Herbert Mead adalah teori sosiologi yang menjelaskan bagaimana individu berinteraksi satu sama lain untuk menciptakan dunia simbolis dan sebagai gantinya bagaimana dunia ini membentuk perilaku individu. Manusia bertindak terhadap sesuatu berdasarkan makna-makna yang ada sesuatu itu bagi mereka, makna tersebut berasal dari "interaksi sosial dengan orang lain", Makna-makna tersebut di sempurnakan di saat proses interaksi sosial berlangsung. Makna tersebut berasal dari interaksi dengan orang lain, terutama dengan orang yang cukup berarti".

\section{b. Apa Implikasi Pendidikan di Kecamatan Tanete Riaja Terhadap Masyarakat Kabupaten Barru}

Berdasarkan kategori implikasi atau efek yang ditimbulkan terhadap pendidikan masyarakat Kecamatan Tanete Riaja bias dikatakan sudah berkemajuan karana sudah banyak bantuan berupa beasiswa dan membentuk namanyanya komunitas pelajar non formal Partisipasi pemerintah terhadap masyarakt ini sering dianggap sebagai bagian yang tidak terlepas dalam upaya sosialisasi anak anak yang tidak mampu sekolah dan tidak dapat terlepas dari peran serta masyarakat. Masyarakat perlu aktif berpartisipasi dan dan mendukung kegiatan pemerintah terhadap pendidikan, sehingga mampu mengembangkan dayanya secara kreatif serta memiliki kesadaran kritis.

Analisis struktural fungsional parsons adalah mekanisme yang meningkatkan stabilitas dan keteraturan dalam sistem sosial. Pendekatan ini fokus pada proses interaksi dalam institusi pendidikan seperti linkungan masyarakat dari interaksi tersebut. Sebagai contoh, interaksi antara pemerintah dengan masyarakat Teori interaksionalisme simbolik melihat bagaimana karakteristik sosial membentuk interaksi sosial seperti interaksi antar gender, kelas, ras, dan sebagainya, dan bagaimana interaksi tersebut menciptakan ekspektasi antara pemerintah dengan masyarakat. 


\section{KESIMPULAN}

Menunjukkan bahwa interaksi sebagai hubungan timbal balik dengan masyarakat khususnya anak anak yang tidak $\mathrm{k}$ mampu melanjutkan sekolah atau yang putus sekolah terutama memberikan motivasi pada si anak ini mengenai pendidikan dan Alhamdulillah peningkatan pendidikan sekarang khususnya di kecamatan sudah bisa dikatakan berkemajuan berkat adanya adanya bantuan pemerintah baik pendidikan formal dan non formal. Interaksi dapat mengubah pola perilaku anak tak mampu sekolah seperti pengetahuan,kecakapan, keterampilan agar terbuka wawasan memberikan keterampilan dasar pada anak tersebut agar bisa menuju jenjang pendidikan yang lebih tinggi lagi dan tak tertinggal lagi yang namanya pendidikan betapa penting nya pendidikan.

Dengan adanya sosialisasi pada anak dapat membuat pola piker mereka meningkat berkat adanya bantuan pemerintah dan dukungan dari orang tua/masrakat itu sendiri. Dengan adanya saling berinteraksi pemerintah dengan masyarakat atau orang tua anak yang kurang mampu akan mengakibatkan terjadi perubahan yang lebih baik terhadap pendidikan anak tersebut sehingga dapat menghasilkan generasi penerus bangsa yang berkemajuan terutama di Kecamatan Tanete Riaja Kabupaten Barru

\section{DAFTAR PUSTAKA}

Creswell, John.W. (2016). Research Design Pendekatan Metode Kualitatif, Kuantitatif dan Campuran. Yogyakarta : Pustaka Belajar.

Darmayanti. (2005) Studi Jangka Panjang Tentang Efektivitas Intervensi Psikologis Dalam Meningkatkan Kemampuan Belajar Mandiri dan Prestasi Belajar Mahasiswa Pendidikan Jarak Jauh, Jakarta: Universitas Indonesia.

Eko Hardi Ansyah dan Effy Wardati Maryam, (2016). Efektivitas Intervensi Milieu dan Komunitas Untuk Meningkatkan Motivasi Berprestasi Anak Panti Asuhan Aisyiyah Celep-Sidoarjo. Universitas Muhammadiyah Sidoarjo.

Firdaus Andrew S.P (2015). Intervensi Terhadap Kedaulatan Suatu Negara Menurut Hukum Internasional. Purwokerto.

H. Hasan Baharun (2012). Desentralisasi dan Implikasinya terhadap pengembangan sitem pendidikan sosial. 1(2). Ilmu Tarbiyah At-Tajdid

Isbandi Rukminto Adi. (2013: 211) Intervensi Komunitas \& Pengembangan Masyarakat: Sebagai Upaya Pemberdayaan Masyarakat. Jakarta. PT Raja Grafindo Persada

John W. Creswell (2014). Research Design Pendekatan Metode Kualitatif, Kuantitatif, dan Campuran Yogyakarta Pustaka Pelajar

Munandar Aris (2011). Fakultas Ilmu Sosial dan Ilmu Politik, Universitas Nasional Jakarta

Naszir dkk. (2009). Teori-Teori Sosiologi. Bandung: Refika Medika.

Ritzer, George (2012) Teori Sosiologi, Bantul : Kreasi Wacana.

Prof. Dr. Soekanto Soerjono dan Dra. Sulistyowati Budi, M.A.(2015). Sosiologi Suatu Pengantar. Jakarta: Rajawali Pers, 2017.

Sugiyono.(2018). Metode Penelitian Pendidikan (Pendekatan Kuantitatif, Kualitatif, dan R\&D). Bandung: Alfabeta.

Tim Penyusun.(2018). Buku Pedoman Penulisan Skripsi. Makassar: Prodi Pendidikan Sosiologi FKIP Universitas Muhammadiyah Makassar 